\title{
A Novel Double Mosaic Virus-like Particle-Based Vaccine against SARS-CoV-2 Incorporates Both Receptor Binding Motif (RBM) and Fusion Domain
}

\author{
Xinyue Chang ${ }^{1,2}$, Andris Zeltins ${ }^{3}$, Mona O. Mohsen ${ }^{1,2,4}$, Zahra Gharailoo ${ }^{1,2}$, Lisha Zha ${ }^{5}$, Xuelan Liu ${ }^{1,2,5}$, \\ Senta Walton ${ }^{4}$, Monique Vogel ${ }^{1,2}$ and Martin F. Bachmann 1,2,5,6,*(D)
}

1 Department of Rheumatology and Immunology, University Hospital Bern, 3010 Bern, Switzerland; xinyue.chang@dbmr.unibe.ch (X.C.); mona.mohsen@dbmr.unibe.ch (M.O.M.); zahra.gharailoo@dbmr.unibe.ch (Z.G.); xuelan.liu@dbmr.unibe.ch (X.L.); monique.vogel@dbmr.unibe.ch (M.V.)

2 Department of BioMedical Research, University of Bern, 3012 Bern, Switzerland

3 Latvian Biomedical Research \& Study Center, Ratsupites 1, LV1067 Riga, Latvia; anze@biomed.lu.lv

4 Saiba GmbH, 8808 Pfäffikon, Switzerland; senta.walton@usz.ch

5 International Immunology Centre, Anhui Agricultural University, Hefei 230036, China; zhalisha@ahau.edu.cn 6 Jenner Institute, University of Oxford, Oxford OX3 7BN, UK

* Correspondence: martin.bachmann@dbmr.unibe.ch

\section{check for}

updates

Citation: Chang, X.; Zeltins, A.; Mohsen, M.O.; Gharailoo, Z.; Zha, L.; Liu, X.; Walton, S.; Vogel, M.; Bachmann, M.F. A Novel Double Mosaic Virus-like Particle-Based Vaccine against SARS-CoV-2 Incorporates Both Receptor Binding Motif (RBM) and Fusion Domain. Vaccines 2021, 9, 1287. https:// doi.org/10.3390/vaccines9111287

Academic Editor: Ralph A. Tripp

Received: 1 October 2021

Accepted: 31 October 2021

Published: 5 November 2021

Publisher's Note: MDPI stays neutral with regard to jurisdictional claims in published maps and institutional affiliations.

Copyright: (c) 2021 by the authors. Licensee MDPI, Basel, Switzerland. This article is an open access article distributed under the terms and conditions of the Creative Commons Attribution (CC BY) license (https:// creativecommons.org/licenses/by/ $4.0 /)$.

\begin{abstract}
COVID-19 has emerged, and has rapidly become a major health problem worldwide, causing millions of mortalities. Vaccination against COVID-19 is the most efficient way to stop the pandemic. The goal of vaccines is to induce neutralizing antibodies against SARS-CoV-2 virus. Here, we present a novel double mosaic virus-like particle (VLP) displaying two independent neutralizing epitopes, namely the receptor binding motif (RBM) located in S1 and the fusion peptide (AA 817-855) located in S2. CuMV were genetically fused in the middle of $\mathrm{CuMV}_{\mathrm{TT}}$ subunits, which co-assembled into double mosaic particles $\left(\mathrm{CuMV}_{\mathrm{TT}}-\mathrm{DF}\right)$. A single fusion mosaic particle $\left(\mathrm{CuMV}_{\mathrm{TT}}-\mathrm{FP}\right)$ containing the fusion peptide only was used for comparison. The vaccines were produced in E. coli, and electron microscopy and dynamic light scattering confirmed their integrity and homogeneity. In addition, the $\mathrm{CuMV}_{\mathrm{TT}}-\mathrm{DF}$ vaccine was well recognized by ACE2 receptor, indicating that the RBM was in native conformation. Both $\mathrm{CuMV}_{\mathrm{TT}}-\mathrm{FP}$ and $\mathrm{CuMV}_{\mathrm{TT}}$-DF vaccines induced high levels of high avidity IgG antibodies as well as $\operatorname{IgA}$ recognizing spike and $\mathrm{RBD}$ in the case of $\mathrm{CuMV}_{\mathrm{TT}}-\mathrm{DF}$. Both vaccine candidates induced virus-neutralizing antibodies indicating that the fusion peptide can independently induce virus-neutralizing antibodies. In contrast, $\mathrm{CuMV}_{\mathrm{TT}}$-DF containing both $\mathrm{RBM}$ and fusion peptide induced a higher level of neutralizing antibodies suggesting that the new double mosaic vaccine candidate $\mathrm{CuMV}_{\mathrm{TT}}$-DF consisting of two antigens in one VLP maybe an attractive candidate for scale-up in a bacterial fermentation process for clinical development.
\end{abstract}

Keywords: COVID19; SARS-CoV-2; vaccine; virus-like particle; $\mathrm{CuMV}_{\mathrm{TT}}-\mathrm{DF}$

\section{Introduction}

Severe acute respiratory syndrome coronavirus 2 (SARS-CoV-2), the cause of the COVID-19 pandemic, was first reported in Wuhan, China [1]. Meanwhile, the virus has infected over 200 million people worldwide and caused more than 4 million fatalities [2]. Despite extensive attempts to treat the disease, there is no curable medication available $[3,4]$. Therefore, global vaccination programs that aim to provide herd immunity are an ideal long-term solution for control of the pandemic.

SARS-CoV-2 utilizes the receptor binding domain (RBD) on spike protein to invade host cells. Like the SARS-CoV-1 virus, RBD of SARS-CoV-2 binds to the angiotensinconverting enzyme 2 (ACE2) receptor and is proteolytically cleaved to allow cellular entry 
of the virus [5]. This offers at least two points of attack for neutralizing antibodies: blocking the interaction of the receptor binding motif (RBM) within RBD with ACE2 [6], or blocking the proteolytic cleavage. There are currently more than 300 vaccine candidates in clinical and preclinical development [7], almost all of which target the spike protein $[8,9]$ except for attenuated or inactivated whole virus [10-13]. There are several vaccines licensed for emergency usage, which are mostly based on nanoparticle-formulated mRNA, inactivated whole virus, or Adenovirus vectors [14].

While all these vaccine platforms have their clear advantages, they also have technical limitations. The main issue for mRNA vaccine is shortage of supply and the very low temperature required for long-term storage [15]. Vaccines based on inactivated whole virus are produced by conventional techniques. However, in the case of SARS-CoV-2, they induce rather low neutralizing responses, an observation compatible with the fact that most individuals infected with virus mount relatively low antibody responses despite sometimes rather high viral load. The same argument extends to attenuated viruses [16-18]. Adenoviruses-based vaccines targeting COVID-19 can easily be produced at large scale and can also be stored at conventional temperature $\left(4^{\circ} \mathrm{C}\right)$. However, it is difficult to apply more than one vaccine injection, which renders it challenging to maintain long-term antibody responses. In an interesting new development, recent studies have demonstrated that "mix and match" vaccines (ChAdOx1 nCoV-19 and BNT162b2) could elicit strong immune responses [19], which suggests that combining different vaccines may overcome drawbacks of individual vaccines. Therefore, more vaccine candidates would increase the chance to meet the demand of global vaccination.

Generally, neutralizing antibodies serve a predominant role in defending viral infections, in particular after vaccination [20,21]. In fact, studies have demonstrated that neutralizing antibodies protect animals and humans from SARS-CoV-2 infection [20,22,23]. Recently, clinical trials using neutralizing IgG antibodies such as cocktail REGN-COV2 [24] and LY-CoV555 [25] have shown positive results in treating COVID-19. In addition to IgG antibodies, IgA antibodies may dominate the mucosal defense in the respiratory tract [26]. Indeed, IgA has been shown to be important for neutralizing SARS-CoV-2 in infected patients [27-29]. Therefore, a good vaccine candidate should elicit strong neutralizing IgG as well as $\operatorname{IgA}$ antibody responses.

Interestingly, a study aiming to identify IgG immunodominant epitopes in spike protein claimed that two linear epitopes (AA 562-579 and AA 818-830) were recognized by convalescent patient sera [30]. Epitope AA 562-579 sits in RBD, but outside of the RBM region and represents a classical neutralizing epitope. Surprisingly, the second epitope AA $818-830$ peptide is located in S2 protein and constitutes an important part of the previously described fusion peptides (AA 816-833) [5,31]. We therefore reasoned that it might be possible to generate a more effective vaccine candidate if such an epitope was to be included in addition to the classical RBD/RBM epitope.

$\mathrm{CuMV}_{\mathrm{TT}}$ VLPs are optimized to activate T helper cells by incorporating a universal tetanus toxin (TT) epitope recognized by memory Th cells of almost every individual due to universal recognition as well as prior vaccination against TT. This epitope has been genetically fused internally to CuMV (cucumber mosaic virus) particles, which has created a powerful vaccine platform currently used for development of prophylactic and therapeutic vaccines in companion animals and humans [32-35]. Since the VLPs are produced by E. coli fermentation, one major advantage of vaccines based on $\mathrm{CuMV}_{\mathrm{TT}}$ is their cost-effectiveness and scalability. Furthermore, $\mathrm{CuMV}_{\text {TT }}$ packages E. coli derived RNA, which represents the best stimulator of TLR7/8 in B cells [36].

To generate a vaccine candidate that effectively protects against SARS-CoV-2 virus, we produced a double mosaic particle by genetically fusing into individual $\mathrm{CuMV}_{\mathrm{TT}}$ subunits the fusion peptide (AA 817-855) and RBM. This double mosaic particle represents a next generation version of the recently reported $\mathrm{CuMV}_{\mathrm{TT}}-\mathrm{RBD}$ and $\mathrm{CuMV}_{\mathrm{TT}}-\mathrm{RBM}$ vaccine candidates, which already demonstrated potent immunogenicity in vaccinated mice $[37,38]$. In contrast to these previously described VLP-based vaccines, the new $\mathrm{CuMV}_{\mathrm{TT}}-\mathrm{DF}$ vaccine 
candidate targets the RBD-ACE2 interaction interface as well as epitope required for fusion of the virus with the endosomal membrane. The $\mathrm{CuMV}_{\mathrm{TT}}-\mathrm{DF}$ immunized mice showed strong IgG and IgA antibody responses, which could effectively neutralize SARS-CoV-2 virus. To our knowledge, this is the first time two different epitopes have been displayed on a single VLP by genetic fusion, extending the potential of VLPs as a better vaccine platform.

\section{Materials and Methods}

\subsection{Ethics Statements}

All studies involving animal were subject to prior approval by the respective local ethics committees. For studies using mice, methods were performed in accordance with regulations and guidelines of the Cantonal Veterinary Office Bern, Switzerland. Methods were approved by the animal ethics research committee of the Cantonal Veterinary Office Bern, Switzerland as part of the standard operating procedure for study approval for project (license BE70/18). No human material was used in this study.

\subsection{Vaccine Production and Characterization}

E. coli ER2566 containing pETDu-CMV3d-nCoV-FP-CMVtt or pET28-CMVB3d-nCoV$\mathrm{M}-\mathrm{CMV}-\mathrm{FP}$ were used to produce $\mathrm{CuMV}_{\mathrm{TT}}-\mathrm{FP}$ and $\mathrm{CuMV}_{\mathrm{TT}}-\mathrm{DF}$ vaccines, respectively. Bacteria were cultured in 2 TY medium (1.6\% tryptone, $1 \%$ yeast extract, $0.5 \% \mathrm{NaCl}$ ) with $100 \mathrm{mg} / \mathrm{L}$ Ampicillin at $30{ }^{\circ} \mathrm{C}$ until $\mathrm{OD}_{600}=0.8$. Then $0.2 \mathrm{mM}$ IPTG (Isopropyl $\beta$-D-1thiogalactopyranoside) and $5 \mathrm{mM} \mathrm{MgCl}_{2}$ were added to induce protein expression at $20^{\circ} \mathrm{C}$. Biomass was harvested by centrifugation $18 \mathrm{~h}$ after induction, and suspended in lysis buffer (20 mM Tris, 5 mM EDTA, 5 mM Et-SH, 5\% glycerol, 10\% sucrose, pH 8.0). VLP vaccines were purified as described previously with minor adjustment [32]. Briefly, bacteria were disrupted with sonication and the lysate was then rotated at $10 \mathrm{rpm}, 4{ }^{\circ} \mathrm{C}$ overnight. Afterwards, VLP-containing supernatants were separated from cell debris with 10,000 rpm centrifugation for $10 \mathrm{~min}$.

VLPs were purified by applying the supernatant to sucrose gradients (20-60\% sucrose in buffer: $20 \mathrm{mM}$ Tris, $2 \mathrm{mM}$ EDTA, 5\% glycerol, 0.5\% Triton X100) and then centrifuged for $6 \mathrm{~h}$ at 25,500 rpm, $18{ }^{\circ} \mathrm{C}$ (Beckman SW32). Afterwards, fractions were collected and analyzed on SDS-PAGE gel, and VLP-containing fractions were 1:1 diluted in buffer $(20 \mathrm{mM}$ Tris- $\mathrm{HCl}, 2 \mathrm{mM}$ EDTA, 5\% glycerol) and then sedimented using 50,000 rpm centrifugation for $4 \mathrm{~h}$ at $4{ }^{\circ} \mathrm{C}$. Finally, VLPs were obtained by dissolving pellets in buffer $(20 \mathrm{mM}$ Tris- $\mathrm{HCl}$, $5 \mathrm{mM}$ EDTA, 5\% glycerol). The quality and purity of VLPs were examined by means of SDSPAGE gel analysis, agarose gel analysis, dynamic light scattering (DLS) and transmission electron microscope (TEM).

The average size of particles was determined by DLS. Briefly, VLPs were diluted to $1 \mathrm{mg} / \mathrm{mL}$ and analyzed by a Zetasizer Nano ZS instrument (Malvern Instruments Ltd., Malvern, UK) [32]. Three repeats were performed.

VLP samples were negatively stained before TEM observation. Firstly, 5 ul of each suspension were adsorbed on glow discharged and carbon coated 400 mesh copper grids (Plano, Wetzlar; Germany) for 1 min. After washing 3 times by dipping in $\mathrm{H}_{2} \mathrm{O}$, grids were stained with $2 \%$ uranyl acetate solution (Electron Microscopy Sciences, Hatfield, PA, USA) for $45 \mathrm{~s}$. The excess fluid was removed by gently pushing them sideways to filter paper. Stained samples were then examined with a transmission electron microscope (Tecnai Spirit, FEI, Hillsboro, OR, USA) at $80 \mathrm{kV}$ and equipped with a digital camera (Veleta, Olympus, Münster, Germany).

\subsection{Mice Immunization}

$B A L B /$ claHsd (Envigo, Horst, The Netherlands) mice were purchased and kept in SPF animal facility (Department of Biomedical Research, University of Bern, Bern, Switzerland) according to Cantonal Veterinary guidelines of Bern. Female mice (8-12 weeks) were immunized subcutaneously with 100 ug purified $\mathrm{CuMV}_{\mathrm{TT}}-\mathrm{FP}, \mathrm{CuMV}_{\mathrm{TT}}-\mathrm{DF}$ vaccine and 
boosted with same dose at 21 days after priming. Serum samples were collected every week until d49. Five mice were used per group.

\subsection{Recombinant Receptor Binding Domain (RBD) of Spike Protein Production}

Gene encoding the RBD protein (319R-541F, $223 \mathrm{AA}$ ) with a His-tag in C-terminus was synthesized by Twist Bioscience HQ (South San Francisco, CA, USA) and cloned into eukaryotic expression plasmid pTwist CMV BetaGlobin WPRE Neo. The expression plasmid was amplified in XL-1 Blue electro-competent cells and then extracted with PureLink $^{\mathrm{TM}}$ HiPure Plasmid Filter Maxiprep Kit (Invitrogen, catalog K210016, Waltham, MA, USA) in accordance with product manual. The Expi293F cells $\left(50 \mathrm{~mL}, 3 \times 10^{6}\right.$ cells $\left./ \mathrm{mL}\right)$ were transfected with 50 ug DNA using transit ExpiFectamine 293 transfection kit (Gibco, catalog A14524, Amarillo, TX, USA). Cell culture supernatants containing RBD protein were collected by $4000 \mathrm{rpm}, 20 \mathrm{~min}$ centrifugation. RBD protein was purified from the supernatants by passing through His-Trap HP column (GE Healthcare, catalog 17-524801, Marlborough, MA, USA) after 0.22 um filtering. Then the purified RBD protein was analyzed in SDS-PAGE gel and stored at $-20^{\circ} \mathrm{C}$.

\subsection{ELISA and Avidity ELISA}

ELISA was performed to determine the immunogenicity of vaccines. Corning half area 96-well plates were coated with $1 \mathrm{ug} / \mathrm{mL}$ recombinant $\mathrm{RBD}$ protein, spike protein (Sino Biological, catalog 40589-V08H4) or spike S2 protein (Sino Biological, catalog 40590V08B) overnight at $4{ }^{\circ} \mathrm{C}$. Then plates were blocked with PBS- $0.15 \%$ Casein for $2 \mathrm{~h}$ at room temperature, after which mice sera were added and 1:3 serial diluted starting from 1:20 dilution in PBS- $0.15 \%$ Casein. After incubation at room temperature for one hour, goat anti-mouse IgG-POX antibody (Jackson Immunoresearch, catalog 115-035-071) was added and incubated for one hour. Finally, plates were developed with tetramethylbenzidine (TMB) in citrate buffer, stopped with $1 \mathrm{M} \mathrm{H}_{2} \mathrm{SO}_{4}$ solution and read at $\mathrm{OD}_{450 \mathrm{~nm}}$.

Same procedures were applied to determine spike-specific IgA antibodies, with exception of goat anti-mouse IgA-POX antibody (ICN Cappel, catalog 55549) as secondary antibody. To eliminate the interference of IgG antibodies to IgA determination, IgG antibodies were removed from serum samples by incubating serum with Protein $\mathrm{G}$ magnetic beads (Thermo Scientific, catalog 88847) at room temperature for $10 \mathrm{~min}$.

To determine if the vaccines were able to be recognized by angiotensin-converting enzyme 2 (ACE2) receptor, the plate was coated with recombinant ACE2-His tag (Sino Biological, catalog 10108-H08H). Then vaccines were added and diluted after blocking the

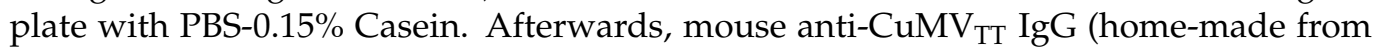
hybridomas) was used to detect the bound vaccine, followed by adding sheep anti-mouse IgG-POX antibody (ICN Cappel, catalog 55558). Finally, the plate was developed and stopped as described above.

To analyze the binding of monoclonal anti-RBD antibody to RBM peptides in $\mathrm{CuMV}_{\mathrm{TT}}-$ $\mathrm{DF}$, half-well Corning plate was coated with anti-CuMV $\mathrm{TT}_{\text {TT }}$ antibody overnight at $4{ }^{\circ} \mathrm{C}$. Then plate was blocked with PBS- $0.15 \%$ Casein for $2 \mathrm{~h}$ at room temperature, after which $\mathrm{CuMV}_{\mathrm{TT}}$-DF (CuMV $\mathrm{TT}$ as a control) vaccine was added to plate and serially diluted. After incubation at room temperature for an hour, human anti-RBD antibody (Sanyou biopharmaceuticals, catalog AHA004, Shanghai, China) was added and incubated for one hour. Finally, goat anti-human IgG conjugated with POX (Nordic MUbio, catalog $\mathrm{GAHu} / \mathrm{IgG}(\mathrm{Fc}) / \mathrm{PO}$, Susteren, The Netherlands) was used as detection antibody. After an hour incubation, plate was developed with $\mathrm{TMB}$ and stopped with $1 \mathrm{M} \mathrm{H}_{2} \mathrm{SO}_{4}$.

To test the affinity of specific antibodies in immunized mouse serum, avidity ELISA was performed. To this end, two parallel plates were performed as above, except one washing step before adding secondary antibody. One plate was washed with PBS- $0.05 \%$ Tween-7 M urea 3 times, while the other with PBS- $0.05 \%$ Tween only, in between which plates were washed with PBS-0.01\% Tween. The weakly bound antibodies are washed 
away with $7 \mathrm{M}$ urea. Avidity index was calculated as ratio of OD (PBS- $0.05 \%$ Tween-7 M urea) to OD (PBS-0.05\% Tween) with same dilution [39].

\subsection{SARS-CoV-2 Virus Neutralization Assay}

Viral neutralization assays were performed as described previously [37]. In brief, serum samples were firstly heat-inactivated at $56{ }^{\circ} \mathrm{C}$ for $30 \mathrm{~min}$. Subsequently, the samples were diluted 2-fold starting from 1:20 dilution until 1:160. 100 TCID50 of SARS-CoV2/ABS/NL20 was added to each diluted serum and incubated for $1 \mathrm{~h}$ at $37^{\circ} \mathrm{C}$. Afterwards, the mixtures were added on a monolayer of Vero cells and incubated for additional 4 days at $37^{\circ} \mathrm{C}$. Finally, the wells were inspected for presence of cytopathic effect (CPE). Titer was expressed as the highest dilution of the serum that fully inhibits the formation of CPE.

\section{Results}

3.1. Purified $C u M V_{T T}-F P$ and $C u M V_{T T}-D F$ Vaccines Are of Homogenous Composition, Packaged with RNA, and in Correct Conformation

The engineered $\mathrm{CuMV}_{\mathrm{TT}}-\mathrm{FP}$ and $\mathrm{CuMV}_{\mathrm{TT}}-\mathrm{DF}$ vaccines were designed to be mosaic particles, which consist of two different subunits as illustrated in Figure 1A: mosaic particle consisting of wild type $\mathrm{CuMV}_{\mathrm{TT}}$ and $\mathrm{CuMV}_{\mathrm{TT}}$ fused with fusion peptide (AA 817-855) ( $\left.\mathrm{CuMV}_{\mathrm{TT}}-\mathrm{FP}\right)$; or double mosaic particle consisting of $\mathrm{CuMV}_{\mathrm{TT}}$ fused with RBM (AA 437-508) and $\mathrm{CuMV}_{\mathrm{TT}}$ fused with the fusion peptide (AA 817-855) (CuMV $\mathrm{TT}_{\mathrm{TT}}$-DF). This latter mosaic particle contains no wild-type subunit. Briefly, we could yield $2.7 \mathrm{mg}$ $\mathrm{CuMV}_{\mathrm{TT}}$-DF VLPs per gram biomass. We have shown previously for $\mathrm{CuMV}_{\mathrm{TT}}-\mathrm{RBM}$ that yields were approximately 50-fold higher in bioreactors [38]. As shown in Figure 1B, SDS-PAGE gel demonstrated the correct sizes of the purified subunits of $\mathrm{CuMV}_{\mathrm{TT}}-\mathrm{FP}$ $(25 \mathrm{kD}$ and $31.4 \mathrm{kD})$ and $\mathrm{CuMV}_{\mathrm{TT}}-\mathrm{DF}(31.4 \mathrm{kD}$ and $35.3 \mathrm{kD})$ vaccines. According to densitometric analysis, we conclude that RBM epitope accounted for $57 \%$ subunits and FP epitope for $43 \%$ in $\mathrm{CuMV}_{\mathrm{TT}}$-DF vaccine, indicating that there are $103 \mathrm{RBM}$ and $77 \mathrm{FP}$ epitopes in each particle approximately. In addition, the self-assembled VLPs spontaneously pack negatively-charged prokaryotic ssRNA which stabilizes the viral structure. Accordingly, Figure $1 \mathrm{C}$ shows in agarose gel analysis that both $\mathrm{CuMV}_{\mathrm{TT}}-\mathrm{FP}$ and $\mathrm{CuMV}_{\mathrm{TT}}-\mathrm{DF}$ vaccines incorporate RNA, resulting in stable VLP vaccines and capacity to stimulate innate pattern receptors TLR7/8 [36]. The long-term stability of $\mathrm{CuMV}_{\mathrm{TT}}-\mathrm{DF}$ vaccine was confirmed by SDS-PAGE and agarose gel after storing the vaccine at $4{ }^{\circ} \mathrm{C}$ for 6 months (Supplementary file: Figure S1). In addition, we analyzed the $\mathrm{CuMV}_{\mathrm{TT}}-\mathrm{DF}$ vaccine after 12 months storage at $4{ }^{\circ} \mathrm{C}$. TEM image in Figure S1C illustrates that $\mathrm{CuMV}_{\mathrm{TT}}-\mathrm{DF}$ shows intact spherical viral structure identical to newly produced VLPs. Similarly, DLS also demonstrates homogeneous particles with an apparent diameter of $70 \mathrm{~nm}$. These results indicate that $\mathrm{CuMV}_{\mathrm{TT}}-\mathrm{DF}$ vaccine is stable at $4{ }^{\circ} \mathrm{C}$ for at least one year.

Furthermore, the purified vaccines were found to be homogenous by DLS and the majority VLPs were approximately $70 \mathrm{~nm}$ in diameter (Figure 1D). Similarly, transmission electron microscopy (TEM) analysis illustrated the vaccines were in typical spherical virus shape (Figure 1E). Taken together, the E. coli produced $\mathrm{CuMV}_{\mathrm{TT}}-\mathrm{FP}$ and $\mathrm{CuMV}_{\mathrm{TT}}-\mathrm{DF}$ vaccines successfully formed intact and stable virus-like particles that incorporated RNA.

To further characterize the vaccine candidates, the ability to bind to the viral receptor ACE2 was examined by ELISA. The RBM-containing $\mathrm{CuMV}_{\mathrm{TT}}-\mathrm{DF}$ vaccine was recognized and bound by ACE2 (Figure 1F), suggesting the RBM was in natural conformation. As expected, $\mathrm{CuMV}_{\mathrm{TT}}-\mathrm{FP}$ vaccine did not show binding to ACE2. Similarly, monoclonal anti-RBD antibody could recognize $\mathrm{CuMV}_{\mathrm{TT}}$-DF (Figure 1G), confirming the fact that RBM in $\mathrm{CuMV}_{\mathrm{TT}}-\mathrm{DF}$ vaccine is in native conformation. 
A Receptor binding motif (RBM, AA 437-508)
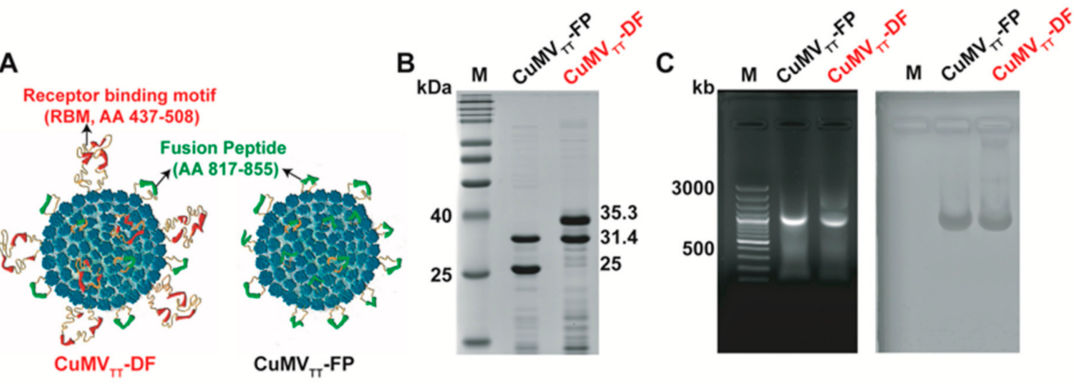

D CuMV $_{T T}$-FP $\mathrm{CuMV}_{\pi}$-DF

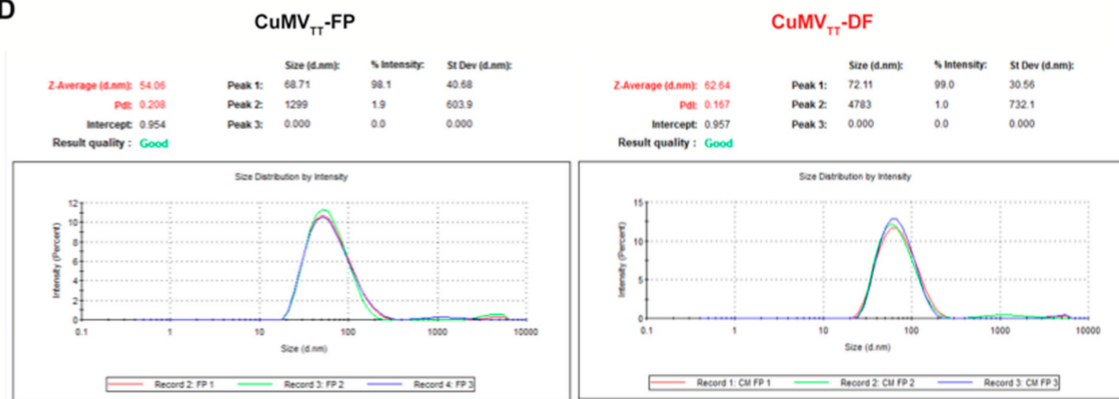

E

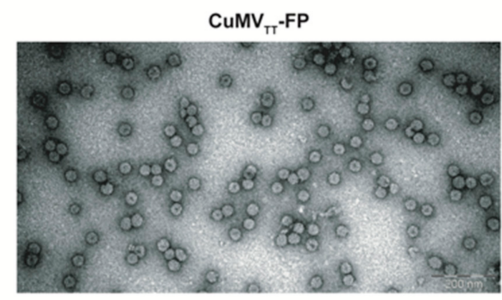

F
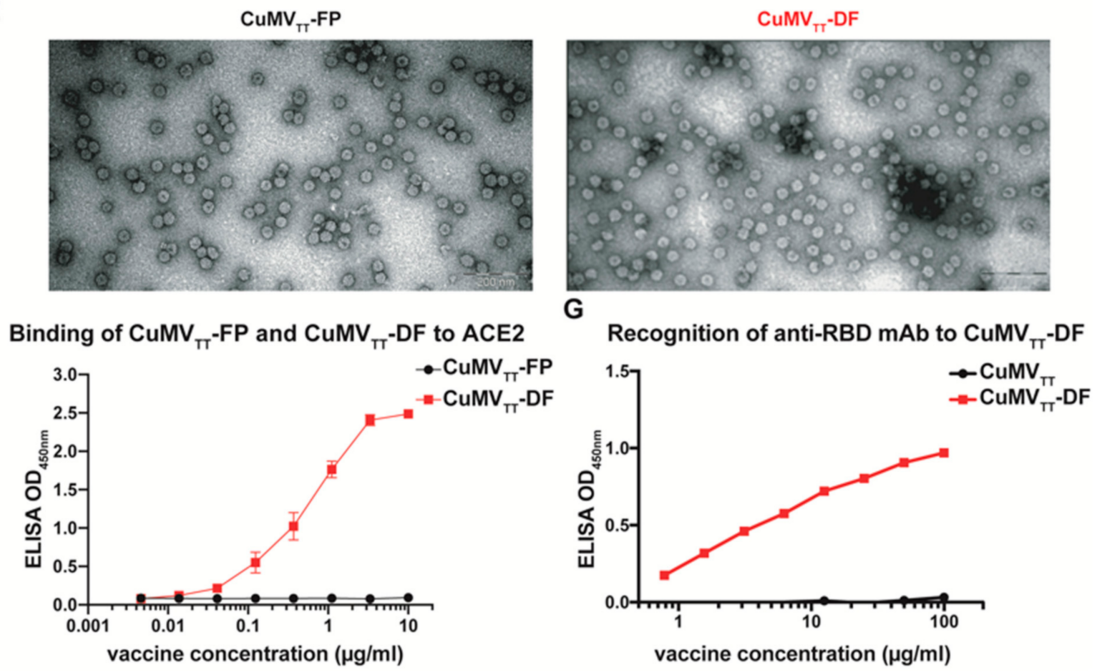

Figure 1. Characterization of $\mathrm{CuMV}_{\mathrm{TT}}-\mathrm{FP}$ and $\mathrm{CuMV}_{\mathrm{TT}}-\mathrm{DF}$ vaccines. (A): Design illustrations of $\mathrm{CuMV}_{\mathrm{TT}}-\mathrm{FP}$ and $\mathrm{CuMV}_{\mathrm{TT}}-\mathrm{DF}$ vaccines; (B): Analysis of purified CuMV $\mathrm{TT}-\mathrm{FP}$ and $\mathrm{CuMV}_{\mathrm{TT}}-\mathrm{DF}$ vaccine on SDS-PAGE gel; (C): Analysis of prokaryotic RNA incorporated in $\mathrm{CuMV}_{\mathrm{TT}}-\mathrm{FP}$ and $\mathrm{CuMV}_{\mathrm{TT}}$-DF VLPs on agarose gel, which was recorded under UV light (left) and afterwards, stained with Coomassie blue (right); (D): Determination of size distribution of $\mathrm{CuMV}_{\mathrm{TT}}-\mathrm{FP}$ and $\mathrm{CuMV}_{\mathrm{TT}}-\mathrm{DF}$ vaccine particles with dynamic light scattering; (E): Transmission electron microscopy analysis of $\mathrm{CuMV}_{\mathrm{TT}}-\mathrm{FP}$ and $\mathrm{CuMV}_{\mathrm{TT}}-\mathrm{DF}$ vaccines; $(\mathbf{F})$ : Binding of $\mathrm{CuMV}_{\mathrm{TT}}-\mathrm{FP}$ and $\mathrm{CuMV}_{\mathrm{TT}}-\mathrm{DF}$ vaccines to ACE2 receptor assessed by Sandwich ELISA; duplicates were performed. (G): Binding of anti-RBD monoclonal antibody to $\mathrm{CuMV}_{\mathrm{TT}}$-DF vaccine assessed by Sandwich ELISA. OD $450 \mathrm{~nm}$ are displayed for serially diluted vaccine solutions.

\section{2. $C u M V_{T T}-F P$ and $C u M V_{T T}-D F$ Vaccines Demonstrated High Immunogenicity in Mice}

To examine the immunogenicity of vaccines in vivo, $B A L B / c$ mice were immunized and serum samples were collected as shown in Figure 2A. Our previous work on another VLP vaccine $C \mathrm{uMV}_{\mathrm{TT}}-\mathrm{RBM}$ demonstrated that $100 \mu \mathrm{g}$ VLP vaccine elicits the best antibody responses [38]. Therefore, we performed our immunization with this dose as well. As expected, $\mathrm{CuMV}_{\mathrm{TT}}$-FP failed to induce RBD-specific antibodies in immunized mice. In contrast, mice immunized with $\mathrm{CuMV}_{\mathrm{TT}}$-DF generated antibodies against RBD, and the titers further increased after booster vaccination (Figure $2 \mathrm{~B}$ ). Consistently, both $\mathrm{CuMV}_{\mathrm{TT}^{-}}$ 
FP and $\mathrm{CuMV}_{\mathrm{TT}}-\mathrm{DF}$ vaccines induced spike S2 protein-specific IgG antibodies in mice and the titers increased with time, in particular after booster immunization (Figure 2C). Furthermore, strong spike protein-specific antibodies were induced by both $\mathrm{CuMV}_{\mathrm{TT}}-\mathrm{FP}$ and $\mathrm{CuMV}_{\mathrm{TT}}-\mathrm{DF}$ (Figure 2D). Titers induced by $\mathrm{CuMV}_{\mathrm{TT}}-\mathrm{DF}$ at $\mathrm{d} 49$ were higher than those induced by $\mathrm{CuMV}_{\mathrm{TT}}-\mathrm{FP}$ immunization, indicating the $\mathrm{CuMV}_{\mathrm{TT}}-\mathrm{DF}$ induces overall better anti-viral responses. In summary, both $\mathrm{CuMV}_{\mathrm{TT}}-\mathrm{FP}$ and $\mathrm{CuMV}_{\mathrm{TT}}-\mathrm{DF}$ vaccines were able to induce potent IgG antibody responses against SARS-CoV-2.

A

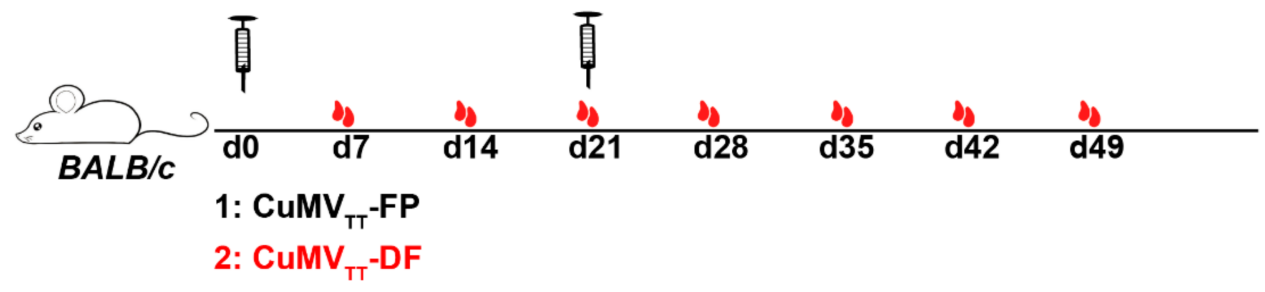

B

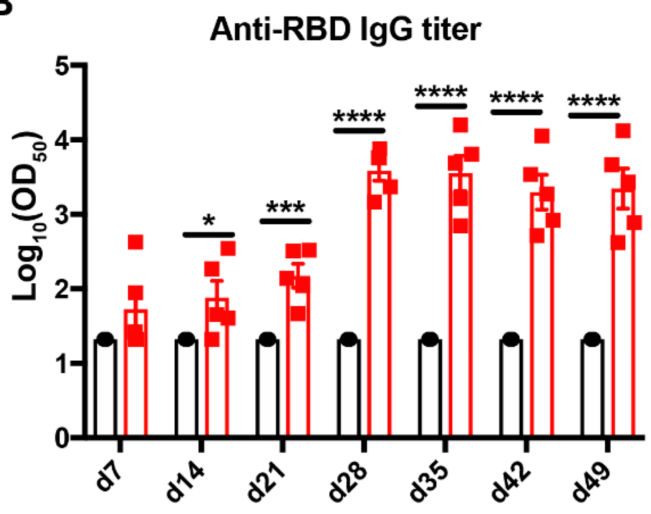

C

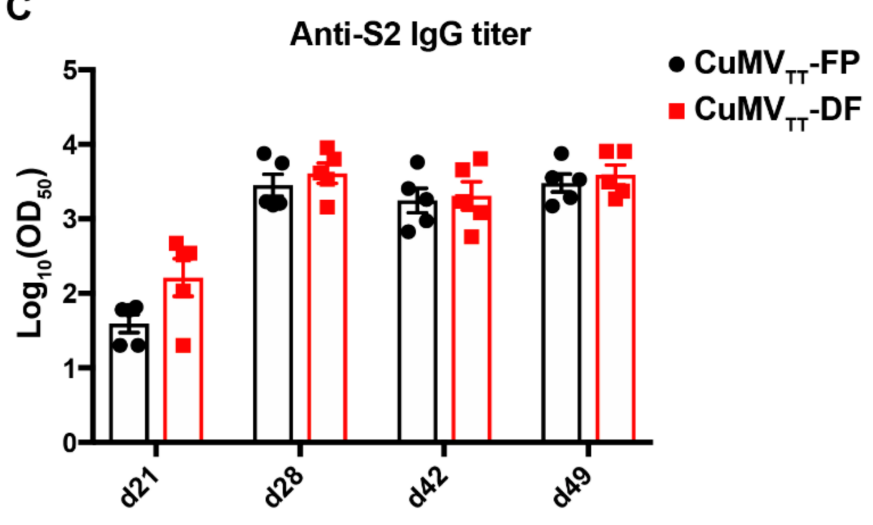

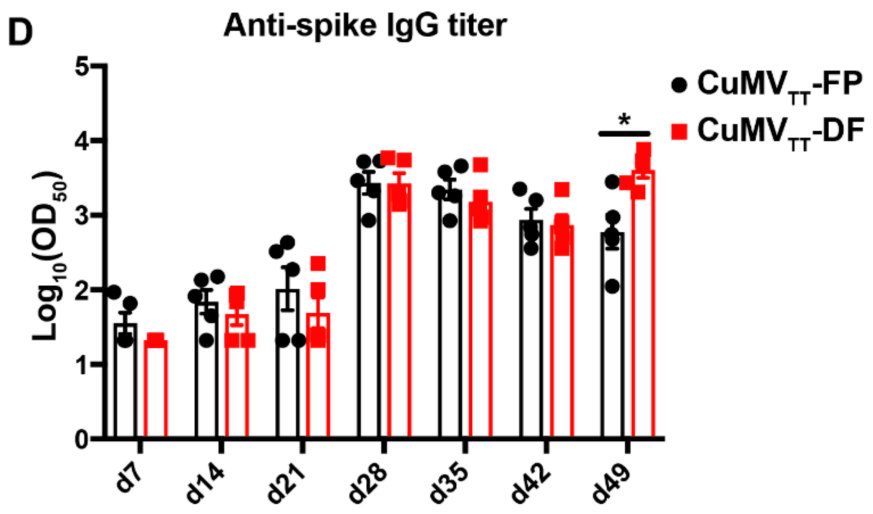

Figure 2. Immunogenicity examination of $\mathrm{CuMV}_{\mathrm{TT}}-\mathrm{FP}$ and $\mathrm{CuMV}_{\mathrm{TT}}-\mathrm{DF}$ vaccines in mice. (A): Immunization regimen: $B A L B / c$ mice were subcutaneously injected with $100 \mathrm{ug} \mathrm{CuMV}_{\mathrm{TT}}-\mathrm{FP}$ or $\mathrm{CuMV}_{\mathrm{TT}}-\mathrm{DF}$ vaccine at $\mathrm{d} 0$ and $\mathrm{d} 21$. Serum samples were collected every week until d49 $(n=5)$. (B-D): IgG antibody titers of immunized mice against RBD (B), S2 protein (C) and spike protein (D). Unpaired $t$-test analysis was performed in GraphPad Prism 7. $\alpha=0.05$ and statistical significance were displayed as $\left.p \leq 0.05\left(^{*}\right), p \leq 0.005{ }^{(* * *)}, p \leq 0.001{ }^{* * * *}\right)$.

High affinity antibodies are needed for good viral neutralization. To examine the avidity of IgG antibodies induced by $\mathrm{CuMV}_{\mathrm{TT}}-\mathrm{FP}$ and $\mathrm{CuMV}_{\mathrm{TT}}$-DF vaccines, avidity ELISA assays were performed. As shown in Figure 3, levels of high-avidity antibodies against RBD (Figure 3B), S2 protein (Figure 3D) and spike protein (Figure 3F) in sera from CuMV $\mathrm{TT}^{-}$ DF immunized mice were elevated in particular after booster immunization. Similarly, avidity indexes against S2 protein (Figure 3C) and spike (Figure 3E) were significantly 
increased after boosting. Importantly, around $50 \%$ of IgG antibodies remain bound to spike protein after $7 \mathrm{M}$ urea wash, indicating the vaccine-elicited IgG antibodies are of very high avidities. Therefore, in addition to high antibody titers, $\mathrm{CuMV}_{\mathrm{TT}}-\mathrm{FP}$ and $\mathrm{CuMV}_{\mathrm{TT}}-\mathrm{DF}$ vaccines induce antibodies of high avidity to SARS-CoV-2.

A

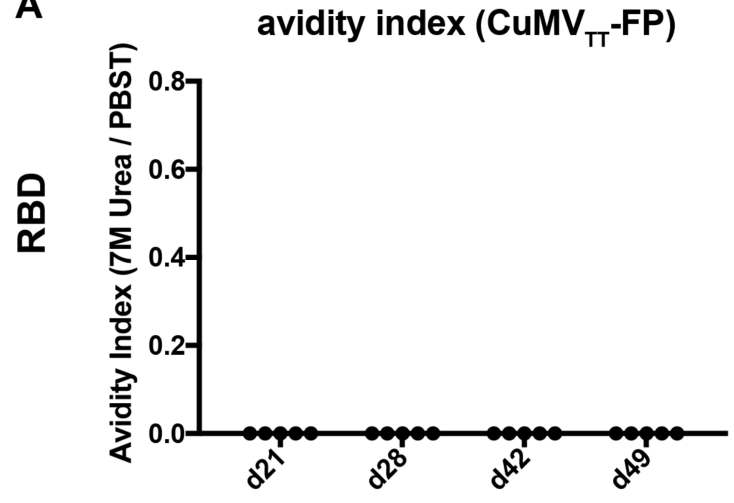

C

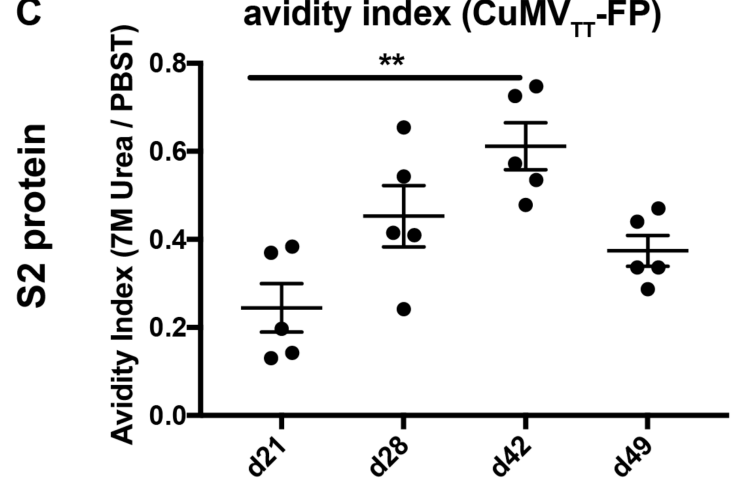

$\mathbf{E}$

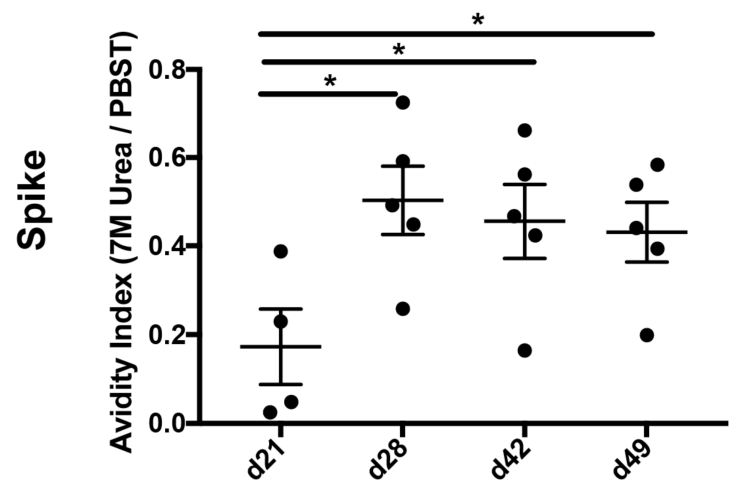

B

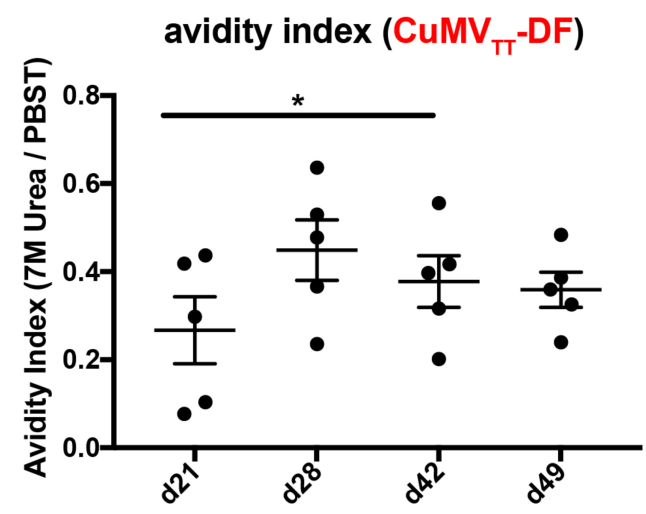

D

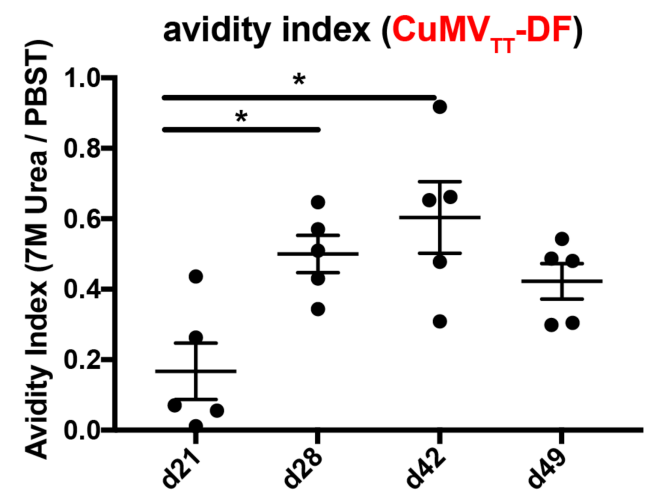

$\mathbf{F}$

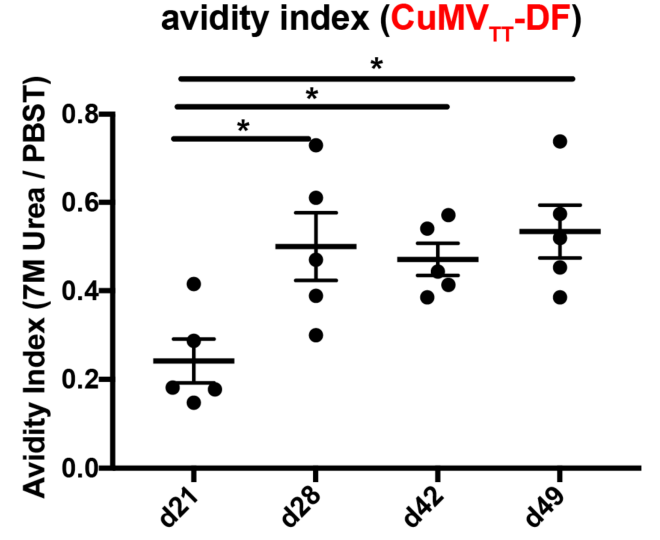

Figure 3. Avidity indexes of IgG antibodies in mice before and after booster immunization of $\mathrm{CuMV}_{\mathrm{TT}}-\mathrm{FP}$ and $\mathrm{CuMV}_{\mathrm{TT}}-\mathrm{DF}$ (right panel, indicated as red) measured by avidity ELISA $(n=5) .(\mathbf{A}, \mathbf{B})$ : Avidity indexes of IgG antibodies for RBD from $\mathrm{CuMV}_{\mathrm{TT}}-\mathrm{FP}(\mathbf{A})$ or $\mathrm{CuMV}_{\mathrm{TT}}-\mathrm{DF}(\mathbf{B})$ immunized mice; (C,D): Avidity indexes for spike $\mathrm{S} 2$ protein of $\mathrm{CuMV}_{\mathrm{TT}}-\mathrm{FP}(\mathbf{C})$ or $\mathrm{CuMV}_{\mathrm{TT}}-\mathrm{DF}(\mathbf{D})$ elicited IgG antibodies; (E,F): Avidity indexes for spike S2 protein of $\mathrm{CuMV}_{\mathrm{TT}}-\mathrm{FP}(\mathbf{E})$ or $\mathrm{CuMV}_{\mathrm{TT}}-\mathrm{DF}$ (F) stimulated IgG antibodies. Paired t-test in GraphPad Prism 7 was used for statistical analysis. $\alpha=0.05$ and statistical significance were displayed as $p \leq 0.05\left(^{*}\right), p \leq 0.01\left(^{* *}\right)$.

Finally, IgA antibodies which typically dominate local anti-viral infections in the respiratory tract were determined. As shown in Figure 4, IgA antibodies were high after booster vaccination and stayed at high levels at least until d49. Taken together, $\mathrm{CuMV}_{\mathrm{TT}}-\mathrm{FP}$ 
and $\mathrm{CuMV}_{\mathrm{TT}}-\mathrm{DF}$ vaccines are highly immunogenic and induce IgG antibodies of high avidity and $\operatorname{Ig} \mathrm{A}$ in mice.
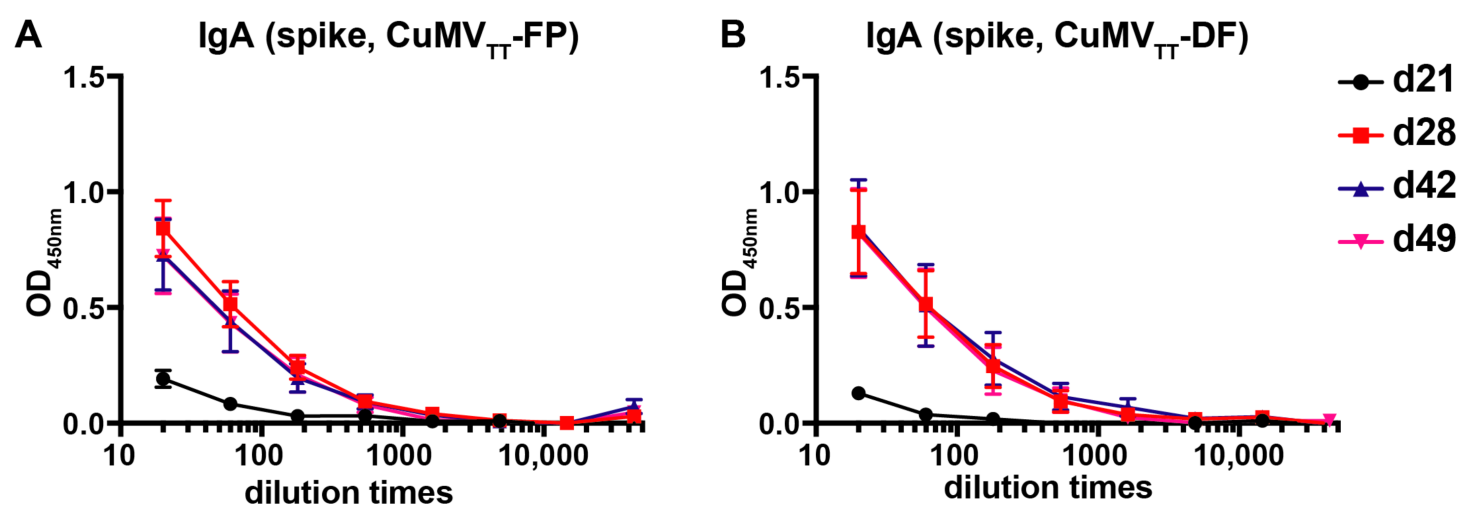

Figure 4. IgA antibodies in $\mathrm{CuMV}_{\mathrm{TT}}-\mathrm{FP}(\mathbf{A})$ and $\mathrm{CuMV}_{\mathrm{TT}}-\mathrm{DF}(\mathbf{B})$ immunized mice sera against spike protein $(n=5)$ before and after booster immunization. Shown are curves of ELISA OD $_{450 \mathrm{~nm}}$ values according to serum dilution, mean \pm SEM.

\section{3. $C u M V_{T T}$-DF Vaccine Induced Neutralizing Antibodies in Mice}

After confirming the potent immunogenicity of $\mathrm{CuMV}_{\mathrm{TT}}-\mathrm{FP}$ and $\mathrm{CuMV}_{\mathrm{TT}}-\mathrm{DF}$ vaccines, we next tested the efficiency of the antibodies to neutralize SARS-CoV-2 virus. Figure 5 shows that neutralization titers induced by both $\mathrm{CuMV}_{\mathrm{TT}}-\mathrm{FP}$ and $\mathrm{CuMV}_{\mathrm{TT}}-\mathrm{DF}$ were significantly higher than control sera (buffer and $\mathrm{CuMV}_{\mathrm{TT}}$ immunized mice [38]), demonstrating that both $\mathrm{CuMV}_{\mathrm{TT}}-\mathrm{FP}$ and $\mathrm{CuMV}_{\mathrm{TT}}-\mathrm{DF}$ vaccines were able to induce neutralizing antibodies. In addition, titers of $\mathrm{CuMV}_{\mathrm{TT}}-\mathrm{DF}$ immunized mice were higher than those from $\mathrm{CuMV}_{\mathrm{TT}}$-FP immunized mice, suggesting that RBM is essential for a vaccine to induce high levels of neutralizing antibodies but that peptide AA 817-855 alone is also able to do so. We have shown previously that $\mathrm{CuMV}_{\mathrm{TT}}-\mathrm{RBM}$ vaccine, which incorporates wild type $\mathrm{CuMV}_{\mathrm{TT}}$ and $\mathrm{CuMV}_{\mathrm{TT}}-\mathrm{RBM}$ subunit, elicited comparable neutralization levels, indicating that RBM is the major contributor to neutralization [38]. Nevertheless, the neutralizing anti-FP antibodies may help avoid viral escape from neutralizing antibodies recognizing RBM alone. In summary, $\mathrm{CuMV}_{\mathrm{TT}}$-DF vaccine could induce antibodies that efficiently neutralize SARS-CoV-2, and thus be an alternative COVID19 vaccine candidate for further clinical development.

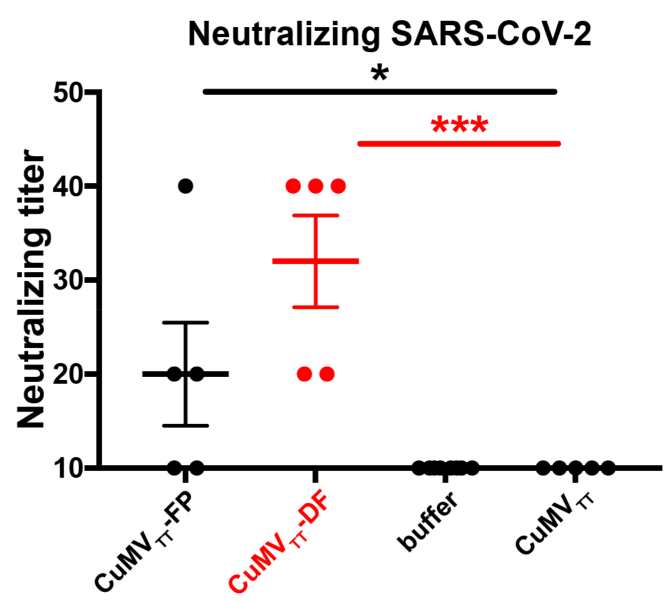

Figure 5. Titers of mice sera at $\mathrm{d} 49$ after $\mathrm{CuMV}_{\mathrm{TT}}-\mathrm{FP}(n=5), \mathrm{CuMV}_{\mathrm{TT}}-\mathrm{DF}(n=5)$, buffer $(n=7)$ or $\mathrm{CuMV}_{\mathrm{TT}}(n=5)$ [38] immunization to neutralize SARS-CoV-2 virus. The titer was expressed as highest serum dilution times to inhibit $100 \%$ cytopathogenic effect (CPE) of cells infected with SARS-CoV-2 virus. Unpaired $t$-test analysis was performed in GraphPad Prism 7. $\alpha=0.05$ and statistical significance were displayed as $p \leq 0.05\left(^{*}\right), p \leq 0.005\left(^{* * *}\right)$. 


\section{Discussion}

Several vaccine candidates based on VLPs against SARS-CoV-2 virus have been tested by us, all of which aimed to induce neutralizing antibodies. The $\mathrm{CuMV}_{\mathrm{TT}}-\mathrm{RBD}$ was our first successful vaccine candidate generated by chemical coupling of RBD protein in native conformation from eukaryotic expression to $\mathrm{CuMV}_{\mathrm{TT}}$ particles, which induced high neutralizing antibodies in immunized mice [37], similarly to RBD displayed on AP205 VLPs by the Spy-Catcher method [40]. On this premise, we next genetically fused the RBM, which has no post-transcriptional modifications, into the middle of $\mathrm{CuMV}_{\mathrm{TT}}$ subunit and produced the mosaic $\mathrm{CuMV}_{\mathrm{TT}}-\mathrm{RBM}$ vaccine in $E$. coli. For this vaccine candidate, we could show that it can be produced at large scale from a stable $E$. coli fermentation process at low costs in short time [38]. Notably, the CuMV TT-RBM vaccine demonstrated as high an immunogenicity as $\mathrm{CuMV}_{\mathrm{TT}}-\mathrm{RBD}$, even several months post vaccination and induced high levels of neutralizing antibodies. In addition, another vaccine candidate based on AP205 VLPs C-terminally fused to RBM (AP205-RBM) demonstrated potent immunogenicity in mice and induced neutralizing antibodies [41].

Even though RBM/RBD are the main neutralizing epitopes on the spike protein, there are additional "minor" epitopes. Even though they are less potent epitopes, they are completely independent of RBM/RBD and therefore may add to more robust neutralization. We therefore combined the minor epitope AA 817-855 situated in S2 with RBM, located in S1 forming a "double fusion" $\mathrm{CuMV}_{\mathrm{TT}}$-DF. Such a vaccine may elicit neutralizing antibodies that block spike-ACE2 interaction as well as blocking fusion of the virion with endosomal membrane. To assess whether AA 717-855 alone can induce neutralizing antibodies, $\mathrm{CuMV}_{\mathrm{TT}}-\mathrm{FP}$ that incorporates this peptide alone was generated and shown to induce neutralizing antibodies, albeit at moderate levels. Thus, $\mathrm{CuMV}_{\mathrm{TT}}-\mathrm{DF}$ induces neutralizing antibodies against two independent epitopes, both conferring neutralization of SARS-CoV-2, and likely reducing the likelihood of viral escape.

Recently, Cohen et al. reported the Spy/Catcher system to convey RBDs from SARSCoV-2 and other Sarbecoviruses on the VLP scaffold, which induced cross-reactive immune responses in mice [42]. Here, instead, we present a direct technique by genetically fusing independent epitopes into one particle. This potential of displaying several antigens on a single VLP may be employed to a variety of novel vaccine candidates. For example, Cervarix and Gardasil vaccines may be optimized to be a "multi-fusion" vaccine [43], instead of mixing individual Human Papillomavirus type 16 and type 18 VLPs together.

Although the $\mathrm{CuMV}_{\mathrm{TT}}-\mathrm{FP}$ vaccine candidate was able to induce antibodies against spike protein in mice, the mice sera neutralized SARS-CoV-2 at low levels in vitro, indicating the chosen epitope was indeed "minor" and not as potent as anti-RBM antibodies. In contrast, sera of mice immunized with $\mathrm{CuMV}_{\mathrm{TT}}-\mathrm{DF}$ vaccine were able to completely neutralize SARS-CoV-2 virus, indicating that RBM was a key epitope to be included in vaccine candidates. The IgG antibodies elicited by $\mathrm{CuMV}_{\mathrm{TT}}-\mathrm{DF}$ vaccine were of high avidity to the spike protein after the booster, and firmly bound to the spike protein, even after $7 \mathrm{M}$ urea wash. This might be an advantage over natural infection, after which the antibodies in blood of convalescent patients only bound RBD weakly to the RBD/spike $[17,44]$ and exhibited much lower avidity to the spike protein than antibodies induced by RNA vaccination [18]. One plausible reason for the better quantity and quality after $\mathrm{CuMV}_{\mathrm{TT}}-\mathrm{DF}$ vaccination than SARS-CoV-2 virus could be its structural features [45]. The long distance $(25 \mathrm{~nm})$ between spikes on the surface of SARS-CoV-2 virus is too large for optimal B cell activation; indeed, optimal antibody responses are induced by epitopes that are rigidly spaced by $5-10 \mathrm{~nm}$, a distance that is found on almost all other viruses [46] and is recognized as pathogen-associated structure patterns (PASP) [47]. In contrast to the virus SARS-CoV-2, the CuMV TT-DF vaccine candidate here presents two epitopes in a repetitive and rigid pattern with an optimal distance of $5-10 \mathrm{~nm}$, as described above to be optimal.

In addition to strong IgG antibodies, IgA was found in immunized mice sera and significantly enhanced after booster immunization. High titers of $\operatorname{IgA}$ antibodies in combination with IgG has been correlated to robust SARS-CoV-2 neutralization in infected 
humans [44]. The presence of serum IgA is, however, not always linked to mucosal IgA and it is necessary to establish whether our vaccine candidate induces mucosal $\operatorname{Ig} \mathrm{A}$ in humans.

\section{Conclusions}

Here we report for the first time a VLP-based vaccine candidate, which displays two different genetically introduced antigens on the surface. With this method, both the major neutralizing RBM epitope in S1 and the independent minor epitope AA817-855 on $\mathrm{S} 2$ protein were successfully incorporated in $\mathrm{CuMV}_{\mathrm{TT}}$, resulting in $\mathrm{CuMV}_{\mathrm{TT}}$-DF vaccine. The $\mathrm{CuMV}_{\mathrm{TT}}$-DF vaccine was shown to be stable, homogenous, and packaged with RNA. In addition, it demonstrated strong immunogenicity and induced robust neutralizing antibodies in mice. Moreover, it may be expected that antibodies are less susceptible to viral escape as both epitopes are independent. In conclusion, $\mathrm{CuMV}_{\mathrm{TT}}$-DF vaccine may not only represent an attractive candidate for a COVID19 vaccine, but also be a pioneer for VLPs displaying multiple antigens by genetic fusion.

Supplementary Materials: The following are available online at https:/ / www.mdpi.com/article / 10.3390/vaccines9111287/s1, Figure S1: SDS-PAGE (A) and agarose (B) gel analysis of $\mathrm{CuMV}_{\mathrm{TT}^{-}}$ DFvaccine after storage at $4{ }^{\circ} \mathrm{C}$ for 6 months; TEM (C) and DLS (D) analysis of CuMV $\mathrm{TT}_{\text {-DFvaccine }}$ after storage at $4^{\circ} \mathrm{C}$ for 12 months.

Author Contributions: X.C., M.V. and M.F.B. wrote and reviewed the manuscript; A.Z. designed and produced the vaccines; M.O.M. and Z.G. performed mouse experiments; X.C. and X.L. performed and analyzed ELISA experiments; L.Z. provided proteins; S.W. coordinated the project. All authors have read and agreed to the published version of the manuscript.

Funding: The work was supported by Saiba AG and the Swiss National Science Foundation (SNF grants 31003A 149925 and 310030-179459).

Institutional Review Board Statement: The study was conducted according to the Cantonal Veterinary guidelines of Bern, Switzerland, and all experiments were performed in accordance with ethical principles and guidelines of the Cantonal Veterinary Office Bern, Switzerland (protocol code BE70/18 and date of approval 1 September 2018).

Informed Consent Statement: Not applicable.

Data Availability Statement: All data generated or analyzed during this study are included in this published article (and its Supplementary Information files).

Conflicts of Interest: M.F.B. declares to be involved in several companies developing vaccines for allergic diseases. The other authors declare no further conflict of interests.

\section{References}

1. Ramanathan, K.; Antognini, D.; Combes, A.; Paden, M.; Zakhary, B.; Ogino, M.; Maclaren, G.; Brodie, D. Clinical features of patients infected with 2019 novel coronavirus in Wuhan, China. Lancet 2020, 395, 497-506.

2. Centro de Recursos Sobre el Coronavirus de la Universidad Johns Hopkins Map @ Coronavirus.Jhu.Edu. Panel Control COVID-19 del Cent. Cienc. e Ing. Sist. 2020. Available online: https://coronavirus.jhu.edu/map.html (accessed on 31 October 2021).

3. Liu, J.; Jiang, Y.; Liu, Y.; Pu, L.; Du, C.; Li, Y.; Wang, X.; Ren, J.; Liu, W.; Yang, Z.; et al. Yindan Jiedu Granules, a Traditional Chinese Medicinal Formulation, as a Potential Treatment for Coronavirus Disease 2019. Front. Pharmacol. 2021, 11, 1-13. [CrossRef]

4. Jin, Y.H.; Cai, L.; Cheng, Z.S.; Cheng, H.; Deng, T.; Fan, Y.P.; Fang, C.; Huang, D.; Huang, L.Q.; Huang, Q.; et al. A rapid advice guideline for the diagnosis and treatment of 2019 novel coronavirus (2019-nCoV) infected pneumonia (standard version). Mil. Med. Res. 2020, 45, 1-20. [CrossRef]

5. Shang, J.; Wan, Y.; Luo, C.; Ye, G.; Geng, Q.; Auerbach, A.; Li, F. Cell entry mechanisms of SARS-CoV-2. Proc. Natl. Acad. Sci. USA 2020, 117, 11727-11734. [CrossRef]

6. Wan, Y.; Shang, J.; Graham, R.; Baric, R.S.; Li, F. Receptor Recognition by the Novel Coronavirus from Wuhan: An Analysis Based on Decade-Long Structural Studies of SARS Coronavirus. J. Virol. 2020, 94, e00127-20. [CrossRef]

7. The COVID-19-Vaccine-Race. Available online: https://www.gavi.org/vaccineswork/covid-19-vaccine-race (accessed on 1 September 2021).

8. Yang, J.; Wang, W.; Chen, Z.; Lu, S.; Yang, F.; Bi, Z.; Bao, L.; Mo, F.; Li, X.; Huang, Y.; et al. A vaccine targeting the RBD of the S protein of SARS-CoV-2 induces protective immunity. Nature 2020, 586, 572-577. [CrossRef] [PubMed] 
9. Su, Q.D.; Zou, Y.N.; Yi, Y.; Shen, L.P.; Ye, X.Z.; Zhang, Y.; Wang, H.; Ke, H.; Song, J.D.; Hu, K.P.; et al. Recombinant SARS-CoV-2 RBD with a built in T helper epitope induces strong neutralization antibody response. Vaccine 2021, 39, 1241-1247. [CrossRef] [PubMed]

10. Seo, S.H.; Jang, Y. Cold-adapted live attenuated SARS-CoV-2 vaccine completely protects human ACE2 transgenic mice from SARS-CoV-2 infection 2 Laboratory of Influenza Research College of Veterinary Medicine Institute of Influenza Virus. bioRxiv 2020, 8, 584 .

11. Sanchez-Felipe, L.; Vercruysse, T.; Sharma, S.; Ma, J.; Lemmens, V.; Van Looveren, D.; Javarappa, M.P.A.; Boudewijns, R.; Malengier-Devlies, B.; Liesenborghs, L.; et al. A single-dose live-attenuated YF17D-vectored SARS-CoV-2 vaccine candidate. Nature 2020, 590, 320-325. [CrossRef]

12. Xia, S.; Zhang, Y.; Wang, Y.; Wang, H.; Yang, Y.; Gao, G.F.; Tan, W.; Wu, G.; Xu, M.; Lou, Z.; et al. Safety and immunogenicity of an inactivated SARS-CoV-2 vaccine, BBIBP-CorV: A randomised, double-blind, placebo-controlled, phase 1/2 trial. Lancet Infect. Dis. 2021, 21, 39-51. [CrossRef]

13. Zhang, Y.; Zeng, G.; Pan, H.; Li, C.; Hu, Y.; Chu, K.; Han, W.; Chen, Z.; Tang, R.; Yin, W.; et al. Safety, tolerability, and immunogenicity of an inactivated SARS-CoV-2 vaccine in healthy adults aged 18-59 years: A randomised, double-blind, placebo-controlled, phase $1 / 2$ clinical trial. Lancet Infect. Dis. 2021, 21, 181-192. [CrossRef]

14. Available online: https:/ / draft-landscape-of-covid-19-candidate-vaccines@www.who.int (accessed on 1 September 2021).

15. Simmons-Duffin, S. Why Does Pfizer's COVID-19 Vaccine Need to Be Kept Colder than Antarctica? Available online: https: / / www.capradio.org/news/npr/story?storyid=935563377 (accessed on 17 November 2020).

16. Lutz, H.; Popowski, K.D.; Dinh, P.-U.C.; Cheng, K. Advanced Nanobiomedical Approaches to Combat Coronavirus Disease of 2019. Adv. Nanobiomed. Res. 2021, 1, 2000063. [CrossRef]

17. Isho, B.; Abe, K.T.; Zuo, M.; Jamal, A.J.; Rathod, B.; Wang, J.H.; Li, Z.; Chao, G.; Rojas, O.L.; Bang, Y.M.; et al. Persistence of serum and saliva antibody responses to SARS-CoV-2 spike antigens in COVID-19 patients. Sci. Immunol. 2020, 5, 1-21. [CrossRef] [PubMed]

18. Chang, X.; Augusto, G.S.; Liu, X.; Kündig, T.M.; Vogel, M.; Mohsen, M.O.; Bachmann, M.F. BNT162b2 mRNA COVID-19 vaccine induces antibodies of broader cross-reactivity than natural infection but recognition of mutant viruses is up to 10-fold reduced. bioRxiv 2021. [CrossRef]

19. Shaw, R.H.; Stuart, A.; Greenland, M.; Liu, X.; Van-Tam, J.S.N.; Snape, M.D. Heterologous prime-boost COVID-19 vaccination: Initial reactogenicity data. Lancet 2021, 397, 2043-2046. [CrossRef]

20. Zost, S.J.; Gilchuk, P.; Case, J.B.; Binshtein, E.; Chen, R.E.; Nkolola, J.P.; Schäfer, A.; Reidy, J.X.; Trivette, A.; Nargi, R.S.; et al. Potently neutralizing and protective human antibodies against SARS-CoV-2. Nature 2020, 584, 443-449. [CrossRef]

21. Murin, C.D.; Wilson, I.A.; Ward, A.B. Antibody responses to viral infections: A structural perspective across three different enveloped viruses. Nat. Microbiol. 2019, 4, 734-747. [CrossRef] [PubMed]

22. Baum, A.; Copin, R.; Ajithdoss, D.; Zhou, A.; Lanza, K.; Negron, N.; Ni, M.; Wei, Y.; Atwal, G.S.; Oyejide, A.; et al. REGN-COV2 antibody cocktail prevents and treats SARS-CoV-2 infection in rhesus macaques and hamsters. Science 2020, 1115, 1110-1115. [CrossRef] [PubMed]

23. Rogers, T.F.; Zhao, F.; Huang, D.; Beutler, N.; Burns, A.; He, W.-H.; Limbo, O.; Smith, C.; Song, G.; Woehl, J.; et al. Isolation of potent SARS-CoV-2 neutralizing antibodies and protection from disease in a small animal model. Science 2020, 963, 956-963.

24. Weinreich, D.M.; Sivapalasingam, S.; Norton, T.; Ali, S.; Gao, H.; Bhore, R.; Musser, B.J.; Soo, Y.; Rofail, D.; Im, J.; et al. REGN-COV2, a Neutralizing Antibody Cocktail, in Outpatients with COVID-19. N. Engl. J. Med. 2021, 384, 238-251. [CrossRef]

25. Chen, P.; Nirula, A.; Heller, B.; Gottlieb, R.L.; Boscia, J.; Morris, J.; Huhn, G.; Cardona, J.; Mocherla, B.; Stosor, V.; et al. SARS-CoV-2 Neutralizing Antibody LY-CoV555 in Outpatients with COVID-19. N. Engl. J. Med. 2021, 384, 229-237. [CrossRef]

26. Woof, J.M.; Ken, M.A. The function of immunoglobulin A in immunity. J. Pathol. 2006, 208, 270-282. [CrossRef] [PubMed]

27. Sterlin, D.; Mathian, A.; Miyara, M.; Mohr, A.; Anna, F.; Claër, L.; Quentric, P.; Fadlallah, J.; Ghillani, P.; Gunn, C.; et al. IgA dominates the early neutralizing antibody response to SARS-CoV-2. Sci. Transl. Med. 2020, 2223. [CrossRef]

28. Wang, Z.; Lorenzi, J.C.C.; Muecksch, F.; Finkin, S.; Viant, C.; Gaebler, C.; Cipolla, M.; Hoffmann, H.-H.; Oliveira, T.Y.; Oren, D.A.; et al. Enhanced SARS-CoV-2 neutralization by dimeric IgA. Sci. Transl. Med. 2021, 13, eabf1555. [CrossRef]

29. Cervia, C.; Nilsson, J.; Zurbuchen, Y.; Valaperti, A.; Schreiner, J.; Wolfensberger, A.; Raeber, M.E.; Adamo, S.; Weigang, S.; Emmenegger, M.; et al. Systemic and mucosal antibody responses specific to SARS-CoV-2 during mild versus severe COVID-19. J. Allergy Clin. Immunol. 2021, 147, 545-557.e9. [CrossRef]

30. Poh, C.M.; Carissimo, G.; Wang, B.; Amrun, S.N.; Lee, C.Y.P.; Chee, R.S.L.; Fong, S.W.; Yeo, N.K.W.; Lee, W.H.; Torres-Ruesta, A.; et al. Two linear epitopes on the SARS-CoV-2 spike protein that elicit neutralising antibodies in COVID-19 patients. Nat. Commun. 2020, 11, 1-7. [CrossRef] [PubMed]

31. Pal, D. Spike protein fusion loop controls SARS-CoV-2 fusogenicity and infectivity. J. Struct. Biol. 2021, 213, 107713. [CrossRef]

32. Zeltins, A.; West, J.; Zabel, F.; El Turabi, A.; Balke, I.; Haas, S.; Maudrich, M.; Storni, F.; Engeroff, P.; Jennings, G.T.; et al. Incorporation of tetanus-epitope into virus-like particles achieves vaccine responses even in older recipients in models of psoriasis, Alzheimer's and cat allergy. NPJ Vaccines 2017, 2, 1-12. [CrossRef] [PubMed]

33. Thoms, F.; Jennings, G.T.; Maudrich, M.; Vogel, M.; Haas, S.; Zeltins, A.; Hofmann-Lehmann, R.; Riond, B.; Grossmann, J.; Hunziker, P.; et al. Immunization of cats to induce neutralizing antibodies against Fel d 1, the major feline allergen in human subjects. J. Allergy Clin. Immunol. 2019, 144, 193-203. [CrossRef] 
34. Thoms, F.; Haas, S.; Erhart, A.; Nett, C.S.; Rüfenacht, S.; Graf, N.; Strods, A.; Patil, G.; Leenadevi, T.; Fontaine, M.C.; et al. Immunization of cats against fel d 1 results in reduced allergic symptoms of owners. Viruses 2020, 12, 288. [CrossRef]

35. Storni, F.; Zeltins, A.; Balke, I.; Heath, M.D.; Kramer, M.F.; Skinner, M.A.; Zha, L.; Roesti, E.; Engeroff, P.; Muri, L.; et al. Vaccine against peanut allergy based on engineered virus-like particles displaying single major peanut allergens. J. Allergy Clin. Immunol. 2020, 145, 1240-1253.e3. [CrossRef]

36. Gomes, A.C.; Roesti, E.S.; El-Turabi, A.; Bachmann, M.F. Type of RNA packed in VLPs impacts IgG class switching-implications for an influenza vaccine design. Vaccines 2019, 7, 47. [CrossRef] [PubMed]

37. Zha, L.; Chang, X.; Zhao, H.; Mohsen, M.O.; Hong, L.; Zhou, Y.; Chen, H.; Liu, X.; Zhang, J.; Li, D.; et al. Development of a vaccine against SARS-CoV-2 based on the receptor-binding domain displayed on virus-like particles. Vaccines 2021, 9, 395. [CrossRef]

38. Mohsen, M.; Balke, I.; Zinkhan, S.; Zeltina, V.; Liu, X.; Chang, X.; Krenger, P.S.; Plattner, K.; Gharailoo, Z.; Vogt, A.S.; et al. A scalable and highly immunogenic virus-like particle-based vaccine against SARS-CoV-2. Allergy 2021, 1-22. [CrossRef]

39. Krueger, C.C.; Thoms, F.; Keller, E.; Leoratti, F.M.S.; Vogel, M.; Bachmann, M.F. RNA and toll-like receptor 7 license the generation of superior secondary plasma cells at multiple levels in a B cell intrinsic fashion. Front. Immunol. 2019, 10, 736. [CrossRef]

40. Fougeroux, C.; Goksøyr, L.; Idorn, M.; Soroka, V.; Myeni, S.K.; Dagil, R.; Janitzek, C.M.; Søgaard, M.; Aves, K.L.; Horsted, E.W.; et al. Capsid-like particles decorated with the SARS-CoV-2 receptor-binding domain elicit strong virus neutralization activity. Nat. Commun. 2021, 12,1-11. [CrossRef]

41. Liu, X.; Chang, X.; Rothen, D.; Derveni, M.; Krenger, P.; Roongta, S.; Wright, E.; Vogel, M.; Tars, K.; Mohsen, M.O.; et al. AP205 VLPs based on dimerized capsid proteins accommodate RBM domain of SARS-CoV-2 and serve as an attractive vaccine candidate. Vaccines 2021, 9, 403. [CrossRef] [PubMed]

42. Cohen, A.A.; Gnanapragasam, P.N.P.; Lee, Y.E.; Hoffman, P.R.; Ou, S.; Kakutani, L.M.; Keeffe, J.R.; Wu, H.J.; Howarth, M.; West, A.P.; et al. Mosaic nanoparticles elicit cross-reactive immune responses to zoonotic coronaviruses in mice. Science 2021, 371, 735-741. [CrossRef]

43. Harper, D.M.; DeMars, L.R. HPV vaccines-A review of the first decade. Gynecol. Oncol. 2017, 146, 196-204. [CrossRef]

44. Noval, M.G.; Kaczmarek, M.E.; Koide, A.; Rodriguez-Rodriguez, B.A.; Louie, P.; Tada, T.; Hattori, T.; Panchenko, T.; Romero, L.A.; Teng, K.W.; et al. Antibody isotype diversity against SARS-CoV-2 is associated with differential serum neutralization capacities. Sci. Rep. 2021, 11, 5538. [CrossRef]

45. Bachmann, M.F.; Mohsen, M.O.; Zha, L.; Vogel, M.; Speiser, D.E. SARS-CoV-2 structural features may explain limited neutralizingantibody responses. NPJ Vaccines 2021, 6, 1-5. [CrossRef] [PubMed]

46. Bachmann, M.F.; Zinkernagel, R.M. The influence of virus structure on antibody responses and virus serotype formation. Immunol. Today 1996, 17, 553-558. [PubMed]

47. Bachmann, M.F.; Jennings, G.T. Vaccine delivery: A matter of size, geometry, kinetics and molecular patterns. Nat. Rev. Immunol. 2010, 10, 787-796. [CrossRef] [PubMed] 